\title{
Sex differences in prevalence of overweight and obesity, and in extent of overweight index, in children and adolescents (3-18 years) from Kraków, Poland in 1983, 2000 and 2010
}

\author{
Małgorzata Kowal ${ }^{1, *}$, Agnieszka Woronkowicz ${ }^{1}$, Łukasz Kryst ${ }^{1}$, Jan Sobiecki ${ }^{1}$ \\ and Maciej W Pilecki ${ }^{2}$ \\ 'Department of Anthropology, Faculty of Physical Education, University of Physical Education, Jana Pawła II 78, \\ 31-571 Kraków, Poland: ${ }^{2}$ Children's and Youth's Psychiatric Clinic, Collegium Medicum, Jagiellonian University, \\ Kraków, Poland
}

Submitted 25 June 2015: Accepted 29 June 2015: First published online 4 August 2015

\begin{abstract}
Objective: The increasing prevalence of overweight and obesity among children is now an important health problem. This fact, however, does not reflect the scale of the problem. The aim of the present study was to find how much the BMI threshold was exceeded in a population from Kraków.

Design: The study was based on three cross-sectional surveys conducted in 1983 , 2000 and 2010. The prevalence of overweight and obesity was estimated based on the International Obesity Task Force cut-off points. In addition to these, an extent of overweight (EOW) index was calculated.

Setting: Poland.

Subjects: Children aged 3-18 years ( $n$ 14 534) from Kraków.

Results: Between the populations examined in 1983 and 2010, the EOW index in boys rose by almost $10 \%$, and the prevalence of overweight and obesity by $39 \%$. In girls, however, the EOW index decreased by $45 \%$, while the prevalence of overweight and obesity remained at similar levels. Analyses in separate age groups showed that the EOW index increased only among early adolescents (150\% for boys, $94 \%$ for girls) and late adolescents (390\% and 64\%, respectively).

Conclusions: The observed increased prevalence of overweight and obesity mainly concerned boys and was accompanied by an increase in the amount by which the BMI threshold values were exceeded.
\end{abstract}

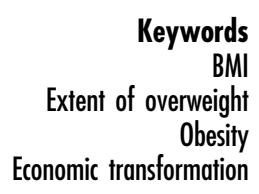

In the 1960 s, Western nations, especially the $\mathrm{USA}^{(1,2)}$ and Western Europe $^{(3)}$, saw a dramatic increase in the frequency of overweight and obesity. In 1998, the $\mathrm{WHO}^{(4)}$ declared obesity a major public health epidemic, both in developed and developing countries, and estimated that by 2025 obesity would concern more than half the adult population in the USA, UK and Australia ${ }^{(4)}$. A similar trend was found among children and adolescents ${ }^{(5,6)}$. In the period 1963-1991 in the USA the prevalence of overweight among 6-11-year-old children increased from $15 \%$ to $22.5 \%$, while the frequency of obesity rose from $5 \%$ to $11 \%$. In the UK in the period 1989-1998 the prevalence of overweight among children under 4 years of age increased from $14.7 \%$ to $23.6 \%$, and obesity from $5.4 \%$ to $9.2 \%$. Between the years 1975 and 1995 in Germany, the frequency of overweight among boys (7-14 years of age) increased from $10.0 \%$ to $16.3 \%$, and among girls from $11.7 \%$ to $20 \cdot 7 \%{ }^{(7)}$. However, relatively recent reports from the USA have shown that the prevalence of overweight and obesity among children and adolescents (2-19 years of age) did not change between 1996 and 2006 or between 2003 and 2006. A slowdown in the trend has also been found among children in the UK, France (children aged 3-14 and 7-9 years), Switzerland (6-13-year-olds) and Sweden (girls 10-11 years old) ${ }^{(8)}$. Nevertheless, it is estimated that at present in the European Union, $20 \%$ of children and young people are overweight, a third of whom can be classified as obese ${ }^{(9)}$. This is very important because obesity during childhood may contribute to orthopaedic complications, metabolic disorders, type 2 diabetes, sleep disorders, impaired immune function and hypertension. In children, obesity can also lead to psychosocial problems such as low self-esteem, social isolation and discrimination from peers. In the case of girls this may further contribute to eating disorders or depression ${ }^{(10,11)}$. Children who are overweight or obese often remain in that 
condition in adulthood, which results in CVD, insulin resistance, type 2 diabetes, hyperlipidaemia, osteoarthritis and some types of cancer ${ }^{(10)}$, thus increasing the risk of premature death $^{(9)}$.

In the early 1990s, Poland and other Eastern Bloc countries started to experience a rapid increase in the prevalence of overweight and obesity among children and adolescents $^{(12,13)}$ due to the dramatic economic, political and social changes after the fall of the Soviet Union ${ }^{(12)}$. In Poland, this trend revealed regional differences which depended on the extent of industrialization. It is estimated that among 11-15-year-old children in Warsaw in 1971, overweight was present in $9.2 \%$ of boys and $8.2 \%$ girls, and obesity in $1.0 \%$ and $0.3 \%$, respectively. More than 20 years later, in the period 2005-2006, the percentage of overweight was already $18.7 \%$ among boys and $11.4 \%$ among girls, with obesity observed in $2.8 \%$ of boys and $3.4 \%$ of girls ${ }^{(14)}$. In another Polish city, Wrocław, located in south-west Poland, Kozieł et al. ${ }^{(15)}$ found a slight decrease in the percentage of overweight and obesity in 14-year-old boys in 1997 (compared with 1987). Among 8-12-year-old children in Rzeszów (south-east Poland) in 1998-2008, the frequency of overweight among boys had increased from $10.5 \%$ to $14.2 \%$, while among girls it had stabilized (12.0\% v. $13 \cdot 3 \%$ ). Obesity decreased among girls (from $10 \cdot 1 \%$ to $7 \cdot 7 \%)$ and stabilized among boys $(6 \cdot 8 \% v \cdot 6 \cdot 4 \%)^{(16)}$.

The WHO defines obesity as a disease associated with the accumulation of excess body fat. Methods allowing a high accuracy in estimating the amount of fat tissue in the body include dual-energy X-ray absorptiometry, dualphoton absorptiometry, computed tomography, MRI and multi-frequency bioelectrical impedance. In clinical practice, a physician would use much simpler and cheaper anthropometric methods, e.g. determination of waist-tohip ratio and waist circumference. BMI is the most commonly used indicator for establishing overweight and obesity, based on the interpretation of the proportion of body mass and height ${ }^{(17)}$. In the case of children and adolescents it is assumed that overweight corresponds to those with a BMI greater than the 85th percentile, and those obese are above the 95 th percentile ${ }^{(18)}$. Recently, the International Obesity Task Force recommended cut-off points suitable for age and sex, the value of which corresponds to a threshold BMI value at the age of 18 years: $25 \cdot 0 \mathrm{~kg} / \mathrm{m}^{2}$ for overweight and $30.0 \mathrm{~kg} / \mathrm{m}^{2}$ for obese $^{(18,19)}$. Importantly, analysis of the frequency of overweight and obesity does not reflect the whole problem. It only relates the number of children in the sample who are overweight or obese. There is a lack of information on what extent overweight people exceed the BMI threshold value and therefore on the extent to which the threshold value is exceeded in the population. This is all the more important as research indicates in the case of overweight people that the likelihood of health problems increases with BMI. For example, the likelihood of heart diseases increases by $5 \%$ among adult men and $7 \%$ among adult women with an increase of one BMI unit. Therefore information solely about BMI and not about how much it exceeds the cut-off points provides little information about the health problems in a population. These observations have been made for adults, and can certainly be applied to children and adolescents ${ }^{(20)}$. Accordingly, Jolliffe ${ }^{(20)}$ proposed a novel indicator, the extent of overweight (EOW) index, which indicates not only the prevalence of overweight and obesity in the population, but also the average value above BMI norms in a given population. In Poland, the index was used for the first time by Chrzanowska ${ }^{(21)}$.

The aim of the present study was to investigate differences in the frequency of overweight and obesity between three populations of minors aged 3-18 years in 1983, 2000 and 2010 in Kraków and to what extent the threshold BMI was exceeded on average. In addition, a similar analysis was carried out in separate groups: children, early adolescents and late adolescents.

\section{Materials and methods}

The children analysed in the present study were included in a cross-sectional survey conducted in randomly selected kindergartens and schools in Kraków, Poland in 2010. The analysis comprised 3833 children (1863 boys and 1970 girls) aged 3-18 years. The cohort was a representation of each of the four traditional residential districts of Kraków. This city is the second biggest in Poland (almost 1 million inhabitants). In order to provide a representative sample, the selection of units for testing (schools and classrooms) was determined at random, taking into account available information sources about the study population. Analysis of the age pyramid of the population of Kraków determined the proportion between the number of boys and girls, and the percentages of each age group in relation to the whole sample. All types of schools were taken into account (kindergarten, primary school, secondary school, basic vocational school, technical school, high school), as well as their location in Kraków. Considering all the above, the target sample size was established in the age groups, along with the number of allocated research institutions and the number of classrooms in a facility in every district. All analysed schools and kindergartens of Kraków were chosen by two-stage lottery, using the urn randomization without replacement method.

The 2010 examinations were conducted according to the procedures in force, i.e. with the consent of the Bioethics Committee at the Regional Medical Association in Kraków (number 26/KBL/OIL/2007) and the consent of children's parents or their legal guardians. The calendar age of the participants, calculated as a difference between the date of the survey and the birth date, expressed as a decimal fraction, was a basis for classifying them as one of sixteen age groups, e.g. the participants aged 5.51-6.50 years were the group of 6-year-old children. 
Children were also divided into three age groups, according to $\operatorname{Bogin}^{(22)}$, as follows:

1. children (including boys aged 3-12 years and girls aged $3-10$ years);

2. early adolescents (including boys aged 13-15 years and girls aged $11-13$ years); and

3. late adolescents (including boys aged 16-18 years and girls aged 14-18 years)

This classification is the result of the difference in tempo of maturation $^{(22)}$.

The data from the 2010 survey series were compared with the results from previous survey series in $1983^{(23)}$ and $2000^{(24)}$. The sample sizes of the previous series were 3158 boys and 3158 girls in 1983, and 2323 boys and 2062 girls in 2000.

All the survey series were conducted by a team of academic researchers of the Department of Anthropology at the University School of Physical Education in Kraków. The measurements were taken according to Martin's technique $^{(25)}$ using a set of tools made by the Swiss manufacturer Sieber Hegner Machines SA. For the measurements, the participants removed their shoes, emptied their pockets and wore light indoor clothing. Height was measured to the nearest $0 \cdot 1 \mathrm{~cm}$. In the 2010 survey series, body composition analyser scales (type BC-418 MA; Tanita, Japan) were used to measure body weight to the nearest $0.01 \mathrm{~kg}$. With this measurement BMI was calculated as weight/height ${ }^{2}\left(\mathrm{~kg} / \mathrm{m}^{2}\right)$.

The estimations of the prevalence of overweight and obesity were based on the cut-off points of the International Obesity Task Force. In this scheme, for overweight and obesity, cut-offs of $25 \mathrm{~kg} / \mathrm{m}^{2}$ and $30 \mathrm{~kg} / \mathrm{m}^{2}$ were extrapolated back to the appropriate age of childhood $^{(19)}$.

To assess the extent of overweight, the following formula proposed by Jolliffe ${ }^{(20)}$ was used:

$$
\text { EOW index }=(1 / n) \sum I\left(\mathrm{BMI}_{i} \geq f_{i}\right)\left[\left(\mathrm{BMI}_{i}-f_{i}\right) / f_{i}\right]
$$

where $n$ is the sample size, $i$ subscript is the child, $f$ is the cut-off point identifying who is overweight and $I$ is an indicator function that takes a value of 1 if the statement is true (the child is overweight) and 0 when the child's BMI is less than the cut-off point corresponding to the value of $\mathrm{BMI} \geq 25 \cdot 0 \mathrm{~kg} / \mathrm{m}^{2}$ for adults, sex- and age-specific.

An advantage of the EOW index is the fact that it treats $\mathrm{BMI}$ as a continuous variable for the overweight segment of the population, while prevalence measures view overweight as a dichotomous outcome. Expressing excess BMI as a proportion of the overweight threshold is particularly important for children since the threshold varies by age and $\operatorname{sex}^{(20)}$. The average extent of overweight for the entire population (EOW), when combined with information about the prevalence of overweight, additionally provides insight into the extent of overweight for that segment of the population ${ }^{(20)}$. In the case of the prevalence of overweight and obesity, the significance of differences between study series was assessed by the $\chi^{2}$ test. All the statistical analyses were made using the StatsDirect $2 \cdot 8$ software.

\section{Results}

Table 1 presents the prevalence of overweight and obesity among boys from the three series of studies. Based on the results, it was found that between 1983 and 2000, the prevalence of either overweight or obesity did not change. However, between 2000 and 2010, the frequency of overweight increased by almost $30 \%$, while obesity doubled - the difference was statistically significant (Table 1, Fig. 1). Analysis in age groups showed that in the last decades of the 20th century, the prevalence of overweight and obesity decreased slightly among children and early adolescents. However, among late adolescents it increased significantly by almost a half. In the first decade of the 21st century it was determined that the prevalence of overweight decreased among the children, while the frequency of obesity increased slightly. In the same period in early adolescents, the prevalence of overweight increased by over $80 \%$ and the frequency of obesity by over $200 \%$. Among the late adolescents, these changes amounted to almost $46 \%$ and $240 \%$, respectively - the differences in both age groups were statistically significant (Table 1, Figs 2 and 3).

Throughout the analysed period (1983-2010), the prevalence of overweight among girls decreased, while obesity increased - the difference was statistically significant (Table 2, Fig. 1). The analysis in age groups showed that in the period 1983-2000 the prevalence of overweight and obesity among children and early adolescents decreased (significantly in the group of children and slightly in the early adolescents group). Among late adolescents the prevalence of obesity was reduced, but overweight increased by over $11 \%$. In the 21 st century, in all age groups slight changes were determined with regard to the prevalence of overweight, but the prevalence of obesity among the children doubled, and among the adolescents increased by over three times. Statistically significant differences were only in younger groups (Table 2, Figs 2 and 3). Additional analysis showed that the differences in the prevalence of overweight and obesity between the sexes were only in the first series of study $(1983)$ among children $(P<0.05)$ and early adolescents $(P<0.05)$ and in the last series (2010) among the early $(P<0 \cdot 01)$ and late adolescents $(P<0 \cdot 001)$. Some non-significant results between age groups can be due to a smaller sample size, but it does not affect the overall observed trends.

Table 3 presents the prevalence of overweight and obesity among boys and girls in the three series of examinations, along with the EOW index and the ratio of these two values (OW gap). It was ascertained that in the 


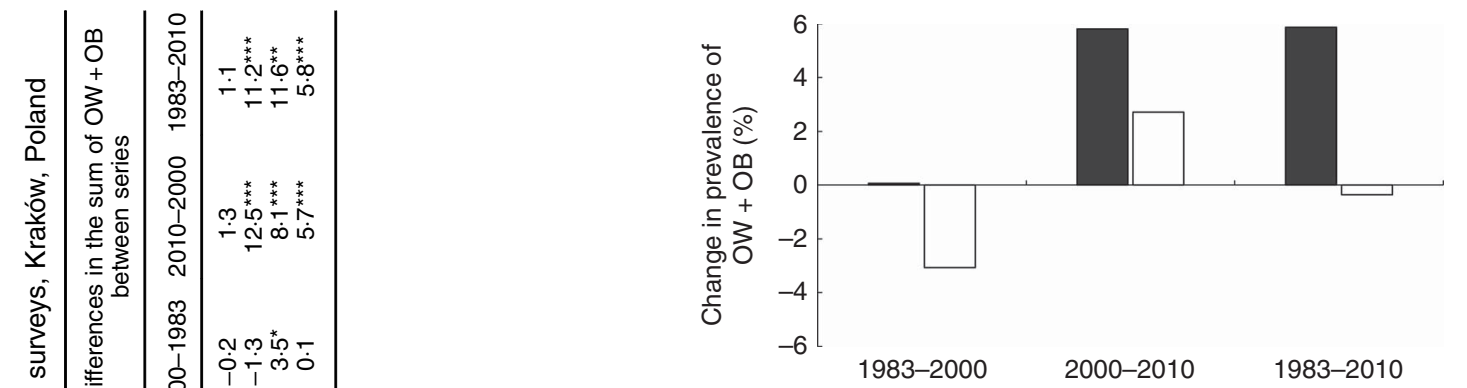

Fig. 1 Percentage changes in the prevalence of overweight (OW) and obesity (OB; according to International Obesity Task Force criteria $\left.{ }^{(19)}\right)$ in boys $(\square)$ and girls $(\square)$ aged 3-18 years ( $n$ 14 534) between three surveys, Kraków, Poland

years 1983-2010 the prevalence of overweight and obesity among boys increased from $15 \%$ to almost $21 \%$ (i.e. by $40 \%$ ), while the EOW index increased by $10 \%$ (Fig. 4). Importantly, the results indicate the prevalence of overweight and obesity in the populations of boys in Kraków increased between 1983 and 2010, while the BMI threshold was exceeded only slightly. Based on the OW gap indicator, it was found that overweight boys in 1983 exceeded the BMI threshold level by $17 \%$, while in 2010 by $13 \%$ (Table 3, Fig. 4).

Among girls the prevalence of overweight and obesity decreased also by $2 \%$, and the EOW index decreased by $45 \%$. As a consequence, the OW gap decreased from $20.4 \%$ to $11.8 \%$. These results show that, on average, girls in 1983 exceeded the BMI threshold value by $20 \%$, while in 2010 by $12 \%$ (Table 3, Fig. 4).

Analysis of changes in the prevalence of overweight and obesity, EOW index and the ratio between these two indicators showed that, in the analysed period (1983-2010) among boys in childhood (<12 years of age), the prevalence of overweight and obesity increased slightly, from $18.1 \%$ to $19.2 \%$ (by $6 \%$ ), while the EOW index decreased from 3.7 to 2.4 (by about $29 \%$; Table 4). In other words, in 2010 there were relatively more overweight boys under 12 years of age than in 1983, although they were slightly leaner than those examined in 1983.

More distinct negative changes were observed in the older age groups. Among the early adolescent boys the prevalence of overweight and obesity increased by $80 \%$ while the EOW index increased by $150 \%$. Among late adolescent boys the changes were $149 \%$ and $390 \%$, respectively, which shows that in 2010 adolescents were more often overweight and also that on average they exceeded the BMI threshold more than in 1983. The excessive body weight was especially pronounced among late adolescents (Table 4, Fig. 5).

Among girls in childhood ( $<12$ years of age) overweight and obesity decreased between 1983 and 2010, and the EOW index decreased by $65 \%$. However, among early adolescent girls the prevalence of overweight and obesity increased by $41 \%$, and the EOW index increased by $94 \%$. Among late adolescents the indicators increased by $16 \%$ 


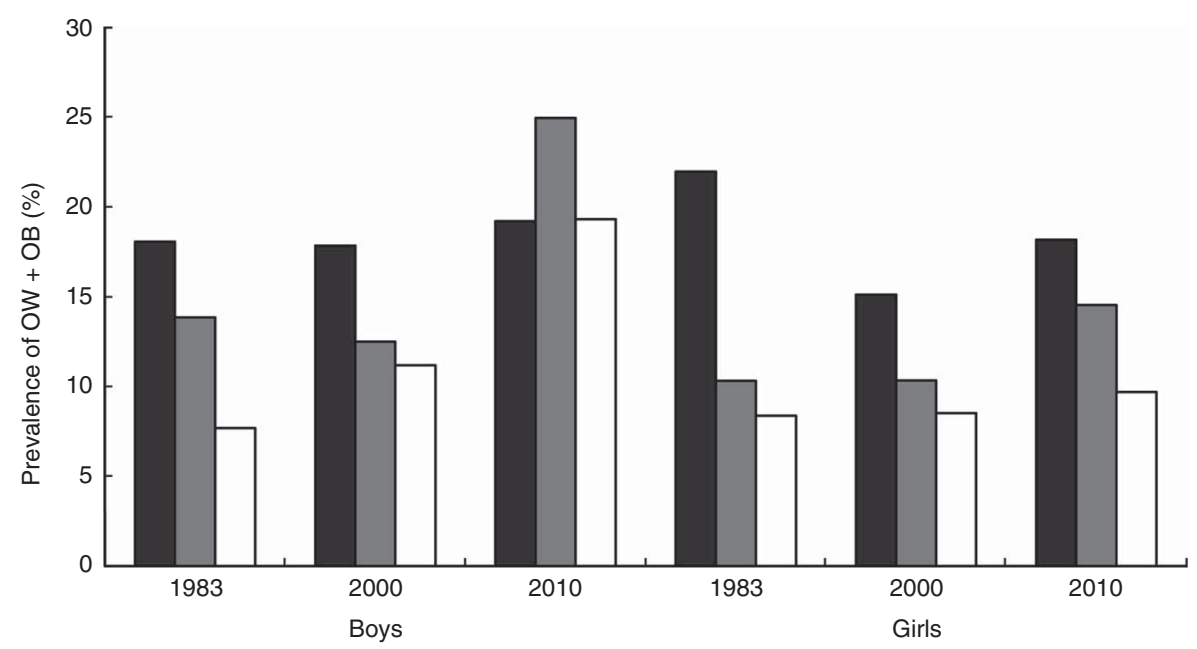

Fig. 2 Prevalence of overweight $(\mathrm{OW})$ and obesity (OB; according to International Obesity Task Force criteria ${ }^{(19)}$ ) in boys and girls aged $3-18$ years $(n$ 14 534) in three surveys according to age group ( $\square$, childhood; $\square$, early adolescence; $\square$, late adolescence), Kraków, Poland

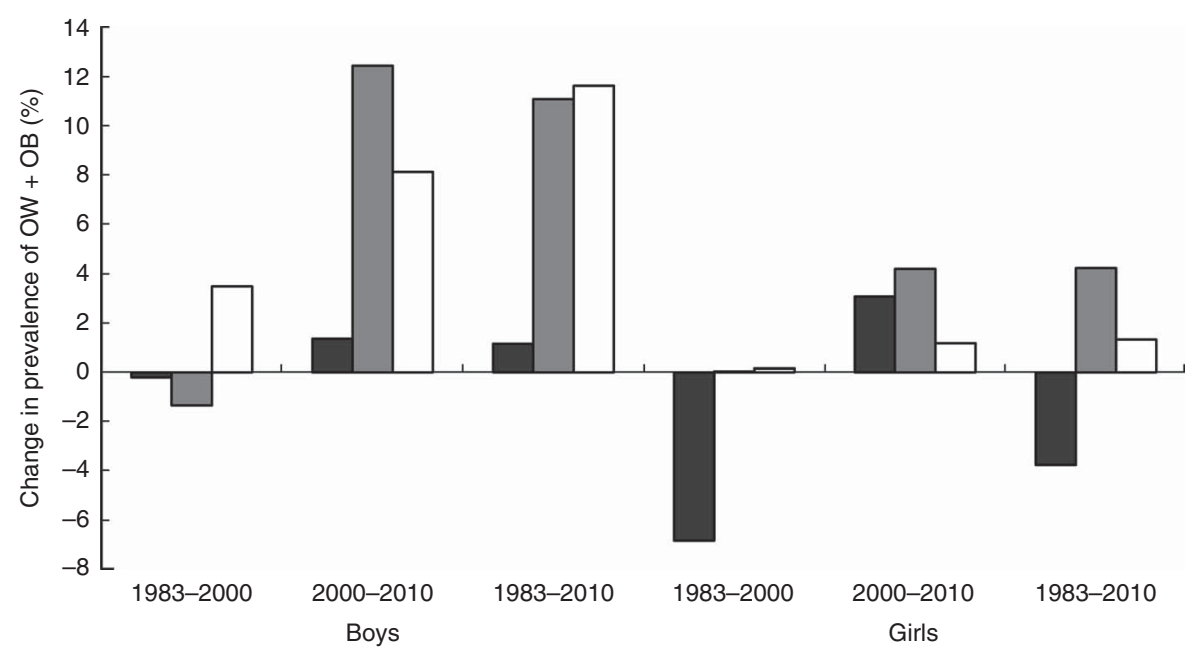

Fig. 3 Percentage changes in the prevalence of overweight (OW) and obesity (OB; according to International Obesity Task Force criteria $\left.^{(19)}\right)$ in boys and girls aged $3-18$ years $(n 14534)$ between three surveys according to age group ( $\square$, childhood; $\square$, early adolescence; $\square$, late adolescence), Kraków, Poland

and $64 \%$, respectively. These results show that among girls in 2010, the prevalence of overweight and obesity was greater in early and late adolescence when compared with 1983 (Table 4, Fig. 6).

The overweight and obese girls examined in 2010 were slightly more overweight than those who exceeded BMI thresholds from 1983. Importantly, the changes in overweight and obesity rates among girls were not as dynamic as among boys, and concerned mainly girls between 11 and 13 years of age.

\section{Discussion}

Our results show no difference between the populations of boys surveyed in 1983 and 2000 in terms of the general prevalence of overweight and obesity. Analysis in individual age groups, however, showed slight decreases in the youngest group age and in the group of early adolescent boys and increases in the group of late adolescent boys. By 2010 the prevalence of overweight and obesity among boys was greater by more than $38 \%$ than in 2000 , and detailed analysis showed increases in these rates in all the individual age groups, especially among early adolescents (by about $100 \%$ ) and late adolescents (by about $73 \%$ ). Based on the OW gap level, it was also observed that the BMI threshold was exceeded most by the boys in childhood in 1983 and by the boys in adolescence in 2010 .

Among girls the prevalence of overweight and obesity did not change significantly from 1983 and 2010, although it was lowest in 2000. A detailed analysis in individual age groups showed that in 2000 the overweight and obesity rate decreased in the youngest age group, while in the remaining groups it did not change significantly. In 2010, the prevalence of overweight and obesity in girls was 
higher compared with 2000, especially in the youngest age group (by about $20 \%$ ) and among early adolescent girls (by more than $40 \%$ ). This showed in the OW gap in the youngest group of girls, which was $17 \%$ greater in 2010 compared with 2000 , and $40 \%$ greater in the group of early adolescent girls.

The periods we are discussing in the present paper are especially significant. The 1980s and 1990s were a time of dramatic increases in the prevalence of overweight and obesity not only among adults, but also among children and adolescents in the USA and many countries of Western Europe ${ }^{(26)}$. These changes ran parallel with the social, economic and lifestyle-related changes ${ }^{(9,10,27)}$. That is why environmental factors, apart from genetic factors, are increasingly often mentioned as the main causes of obesity ${ }^{(28,29)}$. These include low physical activity and the consumption of high-energy and nutrient-poor foods ${ }^{(28,30,31)}$, resulting in an excessive intake of energy ${ }^{(32)}$.

It is estimated in the period 1990-2010 in developed countries that the prevalence of overweight and obesity among 0-5-year-old children increased from $7.9 \%$ to $11.7 \%$ and it is anticipated that in 2020 the problem will concern $14.1 \%$ of children in this age range ${ }^{(33)}$. In the USA, the prevalence of obesity increased during the years 1971-2003 from $4 \%$ to over $18 \%$ among 6-11-year-old children, and from $4.6 \%$ to over $17 \%$ in adolescents ${ }^{(34)}$. In Hungary, the prevalence of overweight and obesity among 7-18-year-old boys increased from about $10 \%$ to about $18 \%$ between 1980 and $2005^{(35)}$. Among Austrian 18 -year-olds it increased from $14 \%$ to almost $19 \%$ in the period 1986-2000 ${ }^{(36)}$. Among Croatian 7-year-old boys, the prevalence of overweight increased from $10 \%$ to $15 \%$ during the period 1991-1999, although obesity decreased from $5 \%$ to $4 \%$. Among Croatian girls of the same age, the rates increased from $7 \%$ to $15 \%$ and from $4 \%$ to $8 \%$, respectively ${ }^{(37)}$.

Our research in Kraków showed no such drastic changes in the corresponding period. On the contrary, in the years 1983-2000 the prevalence of overweight and obesity in boys did not change and among girls it decreased. However, an increased prevalence of overweight and obesity among children and adolescents in Kraków did take place later, in the period $2000-2010$ - by $38 \%$ among boys and by $23 \%$ among girls.

Undoubtedly, the increased prevalence of overweight and obesity among Polish children and adolescents can be linked to changes in the political and economic situation of Poland after 1989. The 1980s was a period of deep economic crisis, a consequence of the inept policies of the communist regime in the 1970s and 1980s (the time of growth for the children and adolescents in the 1983 survey) ${ }^{(38)}$. The costs of transformation from the centrally controlled economy to a market economy ${ }^{(39)}$ resulted in yet another economic crisis in Poland (1990-1991), the period of growth for children surveyed in 2000. Generally, due to a decrease in real income, households were forced 
Table 3 Overweight (OW) and obesity (OB) prevalence (according to International Obesity Task Force criteria ${ }^{(19)}$ ), extent of overweight (EOW) index and the average amount by which the overweight segment of the population exceeds the overweight threshold (avg. OW gap) in boys and girls aged $3-18$ years ( $n$ 14 534) in three surveys, Kraków, Poland

\begin{tabular}{|c|c|c|c|c|c|c|c|c|c|c|c|c|}
\hline & \multicolumn{6}{|c|}{ Boys } & \multicolumn{6}{|c|}{ Girls } \\
\hline & \multicolumn{2}{|r|}{1983} & \multicolumn{2}{|r|}{2000} & \multicolumn{2}{|r|}{2010} & \multicolumn{2}{|r|}{1983} & \multicolumn{2}{|r|}{2000} & \multicolumn{2}{|r|}{2010} \\
\hline & $\%$ & $95 \% \mathrm{Cl}$ & $\%$ & $95 \% \mathrm{Cl}$ & $\%$ & $95 \% \mathrm{Cl}$ & $\%$ & $95 \% \mathrm{Cl}$ & $\%$ & $95 \% \mathrm{Cl}$ & $\%$ & $95 \% \mathrm{Cl}$ \\
\hline $\begin{array}{l}\text { Prevalence of } \mathrm{OW}+\mathrm{OB} \\
\text { EOW index }\end{array}$ & $\begin{array}{r}15 \cdot 0 \\
2.6\end{array}$ & $\begin{array}{c}13 \cdot 8,16 \cdot 3 \\
2 \cdot 0,3 \cdot 2\end{array}$ & $\begin{array}{r}15 \cdot 1 \\
1.7\end{array}$ & $\begin{array}{c}13 \cdot 6,16 \cdot 6 \\
1.2,2 \cdot 2\end{array}$ & $\begin{array}{r}20.8 \\
2.8\end{array}$ & $\begin{array}{c}19 \cdot 0,22 \cdot 6 \\
2 \cdot 1,3 \cdot 6\end{array}$ & $\begin{array}{r}14.7 \\
3.0\end{array}$ & $\begin{array}{c}13 \cdot 5,15 \cdot 9 \\
2 \cdot 4,3 \cdot 6\end{array}$ & $\begin{array}{r}11.6 \\
1.1\end{array}$ & $\begin{array}{c}10 \cdot 2,13 \cdot 0 \\
0.7,1.6\end{array}$ & $\begin{array}{r}14.4 \\
1.7\end{array}$ & $\begin{array}{c}12 \cdot 9,16 \cdot 0 \\
1 \cdot 1,2 \cdot 3\end{array}$ \\
\hline Avg. OW gap & $17 \cdot 3$ & - & 11.3 & - & 13.5 & - & $20 \cdot 4$ & - & 9.5 & - & 11.8 & - \\
\hline
\end{tabular}

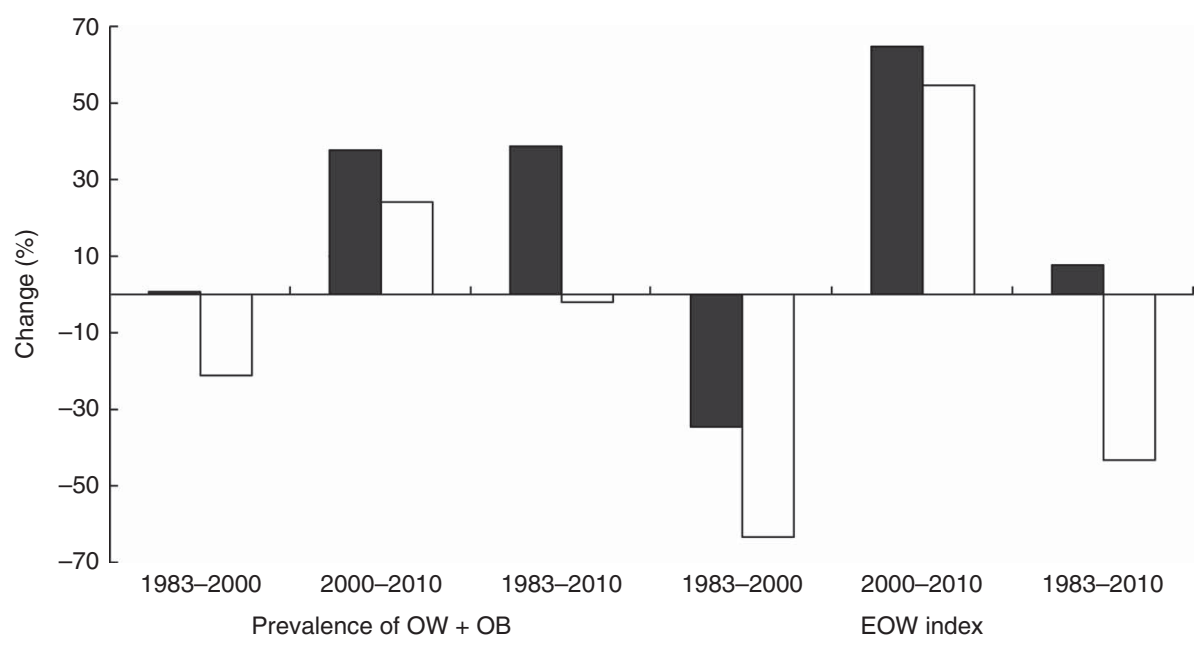

Fig. 4 Percentage changes in the prevalence of overweight (OW) and obesity (OB; according to International Obesity Task Force criteria $^{(19)}$ ) and extent of overweight (EOW) index in boys ( $\square$ ) and girls ( $\square$ ) aged 3-18 years ( $n$ 14 534) between three surveys, Kraków, Poland

to reduce the level and quality of consumption. In the following years (1994-2000), the Polish economy was strengthened by successful structural reforms and a period of dynamic growth ${ }^{(40)}$. The beginning of the 21 st century was a period of economic stagnation, with a weakening economic growth and the associated significant increase in unemployment. In subsequent years (2003-2007) there was a return to the path of rapid economic growth (improvement in the labour market, further reduction in inflation, wage increase) and Polish integration with the European Union ${ }^{(40)}$.

It is therefore obvious that in 2000, compared with 1983 , boys showed no difference in the prevalence of overweight and obesity, except for late adolescents, while among girls one can even see a slight decline. Children and adolescents from 2000 grew up in a period of political and economic change in Poland where living conditions of ordinary citizens were deteriorating.

Positive changes in the Polish economy could be felt only after 2000 (gross domestic product increased from \$US 1547/person in 1990 to \$US 12 000/person in 2004 and \$US $18800 /$ person in 2010) ${ }^{(41)}$, when the material situation improved and the availability of consumer goods increased. Polish accession to the European Union in 2004 resulted in the opening of borders and an intense westernization of the country $^{(16)}$. Unfortunately, it also brought about negative changes in diet and lifestyle, contributing to the increased prevalence of overweight and obesity in 2010, particularly among adolescent boys and girls.

One of the most adverse changes in lifestyle among children, adolescents and adults was undoubtedly a decrease in physical activity ${ }^{(42)}$. Low physical activity may be due to the development of transport and general mechanization of life. Children are transported to preschools and schools by car or bus, which limits their walking opportunities ${ }^{(30,43,44)}$.

Another factor is the uncontrolled access to television (TV) or computers ${ }^{(42)}$. Results of a Canadian study estimate that pre-school children spend $1-5 \mathrm{~h}$ in front of the TV or computer daily ${ }^{(45)}$. Similar data were obtained in the UK, USA, France and Spain ${ }^{(30,43,46)}$. In Poland, nearly $20 \%$ of 2-year-olds spend $3 \mathrm{~h}$ watching TV daily, among 4-12year-olds it is already close to $40 \%$, while among 14 -yearolds it is $42 \%{ }^{(47)}$. In older age groups, extracurricular activities that do not require physical activity (doing homework, studying) result in youths sitting for an average of $4.5 \mathrm{~h} / \mathrm{d}$. Sitting for more than $5 \mathrm{~h} / \mathrm{d}$ is observed among roughly $30 \%$ of boys and $25 \%$ of girls ${ }^{(48,49)}$. 


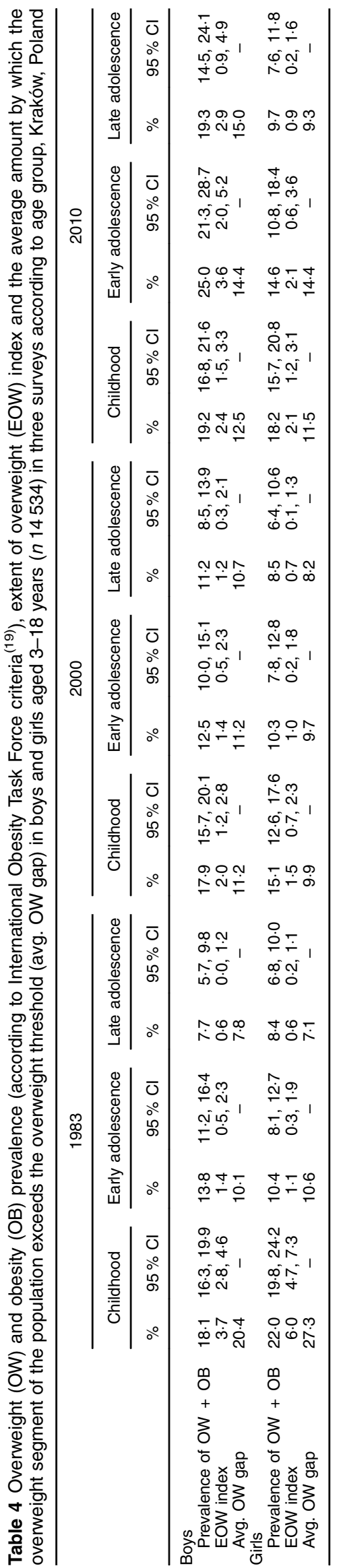

Research carried out in 2005/06 in Warsaw's primary schools showed that extracurricular sports activities were undertaken by only about $38 \%$ of boys and $35 \%$ of girls, and were more often attended by younger students (11-13 years). With age, the percentage of boys in sports activities outside school was significantly reduced; for girls this trend was not observed ${ }^{(48)}$. These results may explain the sharp increase in the prevalence of overweight and obesity among boys in the 2010 series in our study, with the increase in BMI evidenced by the increase in EOW, especially in the older age groups. A similar trend among boys has been seen in the past decade in Portugal, Spain, Greece and Denmark, which researchers attributed to boys spending a large amount of free time on video games ${ }^{(30,50-52)}$.

Studies also show that watching TV encourages more frequent consumption of high-energy snacks ${ }^{(27,28,49,53,54)}$, which is undoubtedly influenced by TV commercials. It is estimated that almost $50 \%$ of TV advertising directed to children relates to food products, where $91 \%$ are high in sugar, fat and salt ${ }^{(27,29,51)}$. The quality of snacks, however, shows some differences based on sex, as confirmed by studies carried out in Denmark, Spain and Norway. Boys are more likely to eat chips, pizza, burgers, sweets, beer and soft drinks. Girls, on the other hand, often consume vegetables and fruit, mineral water and juices ${ }^{(31,51)}$. This may result from more attention girls pay to maintaining a slim figure and a more frequent use of diets ${ }^{(52,55,56)}$.

The problem of weight control has so far been characteristic of the USA and Western Europe where it was found that pre- and adolescent girls are particularly concerned about their figure ${ }^{(29)}$. In Central and Eastern Europe after 1989, a time of political transformation, the ideal of thinness spread as promoted by the Western media. A slim figure, as in Western countries, came to be associated not only with physical attractiveness, but also synonymous with belonging to a higher social class, achieving success in one's career and life ${ }^{(57-59)}$. The perfect figure was to be achieved by diet, with not only late ${ }^{(57)}$ but also early adolescents declaring regular dieting $^{(60)}$. A persistent desire to be slim was declared by $20 \%$ of children aged 9 to 12 years $^{(61)}$. According to national data, in the beginning of the 21st century, $12-40 \%$ of girls were on diets and many of them did so repeatedly. Older girls (16-21 years) were on a diet four times more often than younger girls. It can be argued that the percentage of girls considering themselves fat or convinced of the need for slimming grows with age ${ }^{(62)}$. The slimming of girls observed in our study has also been observed among girls in Poznań (Poland), where the prevalence of overweight among 11-15-year-old girls was $9.6 \%$ and $8.9 \%$ among boys. Among 15-17-year-old girls it was $6.8 \%$, and $9.1 \%$ among boys ${ }^{(63)}$. Our results are also consistent with those in other countries that have undergone a similar transformation as Poland ${ }^{(13,64)}$. Slimming by girls has also been observed in some Western countries ${ }^{(65)}$. The high 


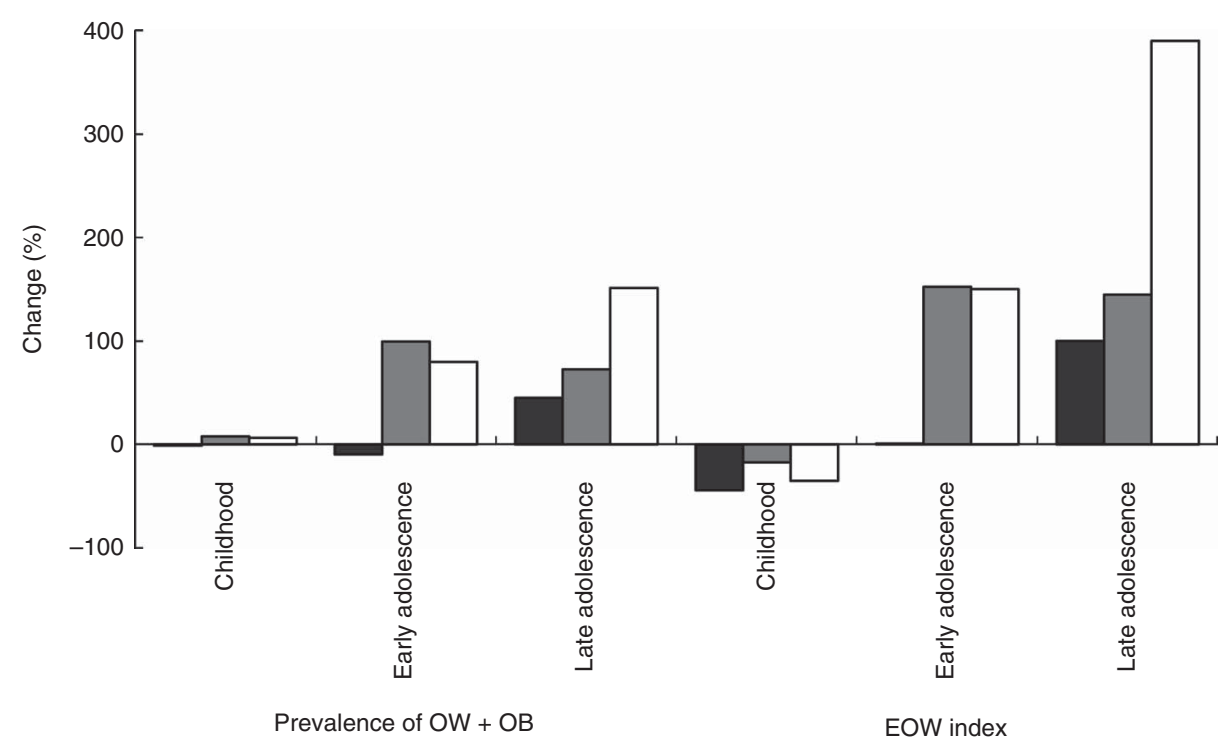

Fig. 5 Percentage changes in the prevalence of overweight (OW) and obesity (OB; according to International Obesity Task Force criteria ${ }^{(19)}$ ) and extent of overweight (EOW) index in boys ( $n$ 7344) aged 3-18 years between three surveys ( $\square$, 1983-2000; $\square$, 2000-2010; $\square$, 1983-2010) according to age group, Kraków, Poland

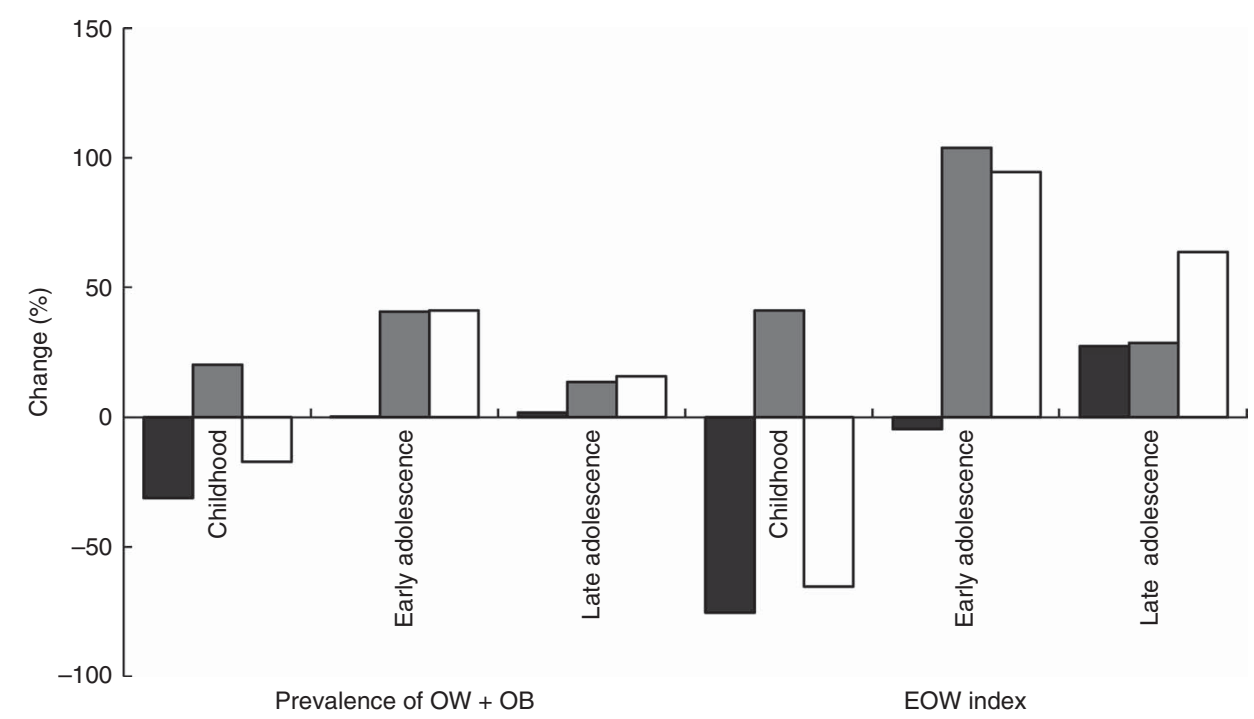

Fig. 6 Percentage changes in the prevalence of overweight (OW) and obesity (OB; according to International Obesity Task Force criteria $^{(19)}$ ) and extent of overweight (EOW) index in girls $(n 7190)$ aged 3-18 years between three surveys ( $\square$, 1983-2000; $\square$, 2000-2010; $\square, 1983-2010$ ) according to age group, Kraków, Poland

percentage of obese girls maintained in the 2010 series may, paradoxically, confirm the desire of girls to attain a slim figure. Adolescents often replace long-term diets with actions meant to bring about the desired effect in the short term. Such activities include unhealthy diets, consisting of dietary restrictions, consumption of diet pills and provoking vomiting. This type of action can produce an opposite effect and cause weight gain, even leading to obesity $^{(66)}$.

In the case of the studied girls in 2010 it is interesting, however, that compared with 2000, we observed a higher percentage of the youngest and early adolescent girls with overweight and obesity and a higher BMI. It does not necessarily have to follow that these girls care less about their figures. It may be more associated with an earlier maturation of girls from the most recent cohort compared with girls examined 30 years earlier. This is evidenced by the time of their menarche (1983, 13.14 years; 2000, $12 \cdot 86$ years; $2010,12 \cdot 68$ years $)^{(67)}$. Sexual maturation is a highly dynamic biological process, associated with changes in volume, proportion and body composition ${ }^{(68)}$, preceded by a sharp increase in body weight, which is reflected in the increase in $\mathrm{BMI}^{(69,70)}$. Children maturing earlier have a higher BMI than their later-maturing peers. Therefore, the use of BMI as a cut-off point for qualifying individuals as overweight may result in incorrect inclusion 
of children who are more developed and not overweight ${ }^{(71)}$. The observed trend is consistent with the results of Vignerová et al. ${ }^{(13)}$. A high percentage of overweight boys in the group of early adolescents in 2010 cannot be explained in the same way. It was observed that boys started to mature earlier, based on the development of pubic hair ${ }^{(72)}$, yet the results of studies on the relationship of adiposity to puberty are not consistent. Some support the increased adiposity in boys with earlier puberty, while others show an opposite trend ${ }^{(73,74)}$.

It should also be noted that despite the unfavourable changes in diet and lifestyle of the youngest age group, we observed no changes in the prevalence of overweight and obesity, and the levels of EOW indicated that children ( $<12$ years of age) in 2010 were slimmer than their peers in 1983. A similar trend was found in recent years in the UK, France (3-14 and 7-9 years), Switzerland (6-13 years), Sweden (girls 10-11 years), the USA ${ }^{(8)}$, Germany, Denmark, Sweden, France ${ }^{(75)}$ and Lithuania ${ }^{(76)}$. This may be due to the fact that back in the 1970s and 1980s (when the children from the 1983 survey were born) overweight children were seen as healthy children, able to overcome malnutrition and infection $^{(77)}$. In subsequent years, excess body weight began to be seen as a health problem. Educational campaigns in the media have contributed to preventive measures being undertaken by parents or guardians of preschool children, to prevent overweight ${ }^{(8,33)}$. These activities involve, among other things, an increase in the number of hours spent by children in an active way, replacing sugary drinks with mineral water ${ }^{(33)}$, and control of the quantity and quality of snacks consumed by children, all being more effective in younger age groups ${ }^{(51)}$.

\section{Conclusion}

In summary, it can be stated that there was an increase in the prevalence of overweight and obesity in children and adolescents in Kraków over the period 2000 to 2010. This is undoubtedly associated with positive socio-economic changes that took place in Poland after 2000. The increased prevalence of overweight and obesity among boys was more intense and occurred in all age groups. Among girls the change in these rates was less intense and concerned mostly the youngest age group and early adolescents.

\section{Acknowledgements}

Financial support: The study survey was part of a project financed by the Polish Council for Science and Technology (grant number NN404 177 035) and by University School of Physical Education in Krakow (grant number 204/KA/206). Conflict of interest: The authors declared no conflict of interest. Authorship: M.K. and L.K. designed the experiment. M.K., A.W., Ł.K., J.S. and M.W.P. performed the experiment. A.W. and J.S. did all the calculations. M.K. wrote the first draft of this paper. M.K., Ł.K. and M.W.P. interpreted the results and contributed to later drafts, including the present paper. All authors were involved in data interpretation and critical revisions of the paper. All authors read and approved the final revised draft for publication. Ethics of buman subject participation: The 1983 and 2000 examinations did not require ethical approval. The 2010 examinations were conducted according to the procedures in force, i.e. with the consent of the Bioethics Committee at the Regional Medical Association in Krakow (number 26/KBL/OIL/2007) and the consent of children's parents or their legal guardians.

\section{References}

1. Flegal KM, Carroll MD, Kuczmarski RJ et al. (1998) Overweight and obesity in United States: prevalence and trends, 1960-1994. Int J Obes Relat Metab Disord 22, 39-47.

2. Flegal KM, Carroll MD, Ogden CL et al. (2002) Prevalence and trends in obesity among US adults, 1999-2000. JAMA 288, 1723-1727.

3. Lobstein T, Rugby N \& Leach R (2005) Obesity in Europe - 3. Brussels: International Obesity Task Force.

4. World Health Organization (2000) Obesity: Preventing and Managing the Global Epidemic. Report of a WHO Consultation. WHO Technical Report Series no. 894. Geneva: WHO.

5. Reilly JJ, Armstrong J, Dorosty AR et al. (2005) Early life risk factors for obesity in childhood: cohort study. BMJ 330, 1357-1359.

6. Wang Y \& Lobstein T (2006) Worldwide trends in childhood overweight and obesity. Int J Pediatr Obes 1, 11-25.

7. Rolland-Cachera MF, Castetbon K, Arnault N et al. (2002) Body mass index in 7-9-y-old French children: frequency of obesity, overweight and thinness. Int J Obes Relat Metab Disord 26, 1610-1616.

8. Stamatakis E, Wardle J \& Cole TJ (2010) Childhood obesity and overweight prevalence trends in England: evidence for growing socioeconomic disparities. Int J Obes (Lond) $\mathbf{3 4}$, $41-47$.

9. Cattaneo A, Monasta L, Stamatakis E et al. (2010) Overweight and obesity in infants and pre-school children in the European Union: a review of existing data. Obes Rev 11, 389-398.

10. Doak CM, Visscher TLS, Renders CM et al. (2006) The prevention of overweight and obesity in children and adolescents: a review of interventions and programmes. Obes Rev 7, 111-136.

11. Striegel-Moore RH \& Bulik CM (2007) Risk factors for eating disorders. Am Psychol 62, 181-198.

12. Ulijaszek SJ \& Koziel S (2007) Nutrition transition and dietary energy availability in Eastern Europe after the collapse of communism. Econ Hum Biol 5, 359-369.

13. Vignerová J, Humeníkowá L, Paulová M et al. (2008) Prevalence of overweight, obesity and low weight in the Czech child population up to 18 years of age in the last 50 years. J Public Health 16, 413-420.

14. Jarosz M, Szponar L \& Rychlik E (2006) Nadwaga, otyłość, niedożywienie w Polsce. In Otyłość, żywienie, aktywność fizyczna, zdrowie Polaków, pp. 45-114 [M Jarosz, editor]. Warszawa: Instytut Żywności i Żywienia.

15. Kozieł S, Kołodziej H \& Uliaszek SJ (2000) Parental education, body mass index and prevalence of obesity among 14 years old boys between 1987 and 1997 in Wroclaw, Poland. Eur J Epidemiol 16, 1163-1167.

16. Mazur A (editor) 2009) Dynamika zmian nadwagi $i$ otyłości u dzieci szkolnych. Rzeszów: Wydawnictwo Uniwersytetu Rzeszowskiego. 
17. Mikoś M, Mikoś M, Mikoś H et al. (2010) Nadwaga i otyłość u dzieci i młodzieży. Now Lek 79, 397-402.

18. Formiguera X (2004) Obesity: epidemiology and clinical aspects. Best Pract Res Clin Gastroenterol 18, 1125-1146.

19. Cole TJ, Bellizzi MC, Flegal KM et al. (2000) Establishing a standard definition for child overweight and obesity worldwide: international survey. BMJ 320, 1240-1243.

20. Jolliffe D (2004) Extent of overweight among US children and adolescents from 1971 to 2000. Int J Obes Relat Metab Disord 28, 4-9.

21. Chrzanowska M (2010) Ekspansja nadwagi w populacji dzieci i młodzieży Krakowa w okresie 1971-2000 w świetle wskaźnika EOW (Extent of Overweight). Pediatr Pol 85 481-484.

22. Bogin B (1999) Evolutionary perspective on human growth. Annu Rev Anthropol 28, 109-153.

23. Chrzanowska M, Gołąb S, Bocheńska Z et al. (editors) (1988) The Child of Cracow. The Level of the Biological Development in the Cracow Children and Youth. Monografie nr 34. Kraków: AWF (in Polish).

24. Chrzanowska M, Gołąb S, Żarów R et al. (editors) (2000) The Child of Cracow 2000. The Level of the Biological Development in the Cracow Children and Youth. Studia $i$ Monografie nr 19. Kraków: AWF.

25. Martin R \& Saller K (editors) (1957) Lebrbuch der Antropologie. Stuttgart: Fisher.

26. Janssen I, Katzmarzyk PT, Boyce WF et al. (2005) Comparison of overweight and obesity prevalence in schoolaged youth from 34 countries and their relationships with physical activity and dietary patterns. Obes Rev 6, 123-132.

27. Strauss R (1999) Childhood obesity. Curr Probl Pediatr 29, $1-29$.

28. Caterson ID \& Gill TP (2002) Obesity: epidemiology and possible prevention. Best Pract Res Clin Endocrinol Metab 16, 595-610.

29. Tabacchi G, Giammanco S, La Guardia M et al. (2007) A review of the literature a new classification of the early determinants of childhood obesity: from pregnancy to the first years of life. Nutr Res 27, 587-604.

30. Rey-Lopez JP, Vicente-Rodríguez G, Biosca M et al. (2008) Sedentary behaviour and obesity development in children and adolescents. Nutr Metab Cardiovasc Dis 18, 242-251.

31. Rey-Lopez JP, Vicente-Rodríguez G, Répásy J et al. (2011) Food and drink intake during television viewing in adolescents: the Healthy Lifestyle in Europe by Nutrition in Adolescence (HELENA) study. Public Health Nutr 14, 1563-1569.

32. Suchocka Z (2003) Otyłość-przyczyny i leczenie. Biul Wydz Farm $A M W$ 1, 1-10.

33. De Craemer M, De Decker E, De Bourdeaudhuij I et al. (2013) Physical activity and beverage consumption in preschoolers: focus groups with parents and teachers. BMC Public Health 13, 278.

34. Harris KC, Kuramoto LK, Schulzer M et al. (2009) Effect of school-based physical activity interventions on body mass index in children: a meta-analysis. CMAJ 180, 719-726.

35. Mészáros Z, Mészáros E, Vögyi E et al. (2008) Body mass and body fat in Hungarian schoolboys: differences between 1980-2005. J Psychol Anthropol 27, 241-245.

36. Schober E, Rami B, Kirchengast S et al. (2007) Recent trend in overweight and obesity in male adolescents in Austria: a population-based study. Eur J Pediatr 166, 709-714.

37. Bralić I, Tahirović H \& Matanić D (2011) Growth and obesity in 7-year-old Croatian children: secular changes from 1991-2008. Eur J Pediatr 170, 1521-1527.

38. Krakowińska E (2007) Społeczne skutki transformacji gospodarki - Polska bieda. In Czynniki wzrostu gospodarczego $w$ Polsce 2006+, pp. 199-231 [K Ryć and M Dusza, editors]. Warszawa: Wydawnictwo Naukowe Wydziału Zarządzania Uniwersytetu Warszawskiego.
39. Piech K (2003) Cykl koniunkturalny Polski a światowy cykl koniunkturalny - wnioski dla polskiej polityki stabilizacyjnej. In Przemiany $i$ perspektywy polskich przedsiębiorstw w dobie integracji z unia Europejska, pp. 141-155 [K Piech and G Szczodrowski, editors]. Warszawa: Instytut Wiedzy.

40. Grzega U (2009) Ocena transformacji polskiej gospodarki w oparciu o mierniki konsumpcji. In Gospodarka polska po 20 latach transformacji: osiagnięcia, problemy $i$ wyzwania, pp. 95-112 [S Pangsy-Kania and G Szczodrowski, editors]. Warszawa: Instytut Wiedzy i Innowacji.

41. Index Mundi (2014) Poland GDP - per capita (PPP). http:// www.indexmundi.com/poland/gdp_per_capita_\%28ppp\% 29.html (assessed March 2014).

42. Sigmundová D, Sigmind E, Hamrik Z et al. (2013) Trend of overweight and obesity, physical activity and secular sedentary behaviour in Czech schoolchildren: HBSC study. Eur J Public Health 24, 210-215.

43. Molnár D \& Livingstone B (2000) Physical activity in relation to overweight and obesity in children and adolescents. Eur J Pediatr 159, Suppl. 1, S45-S55.

44. Azambuja AP, Netto-Oliveira ER, de Oliveira AA et al. (2013) Prevalence of overweight/obesity and economical status of schoolchildren. Rev Paul Pediatr 31, 166-171.

45. He M, Irwin JD, Bouck MS et al. (2005) Screen-viewing behaviours among preschoolers parents' perceptions. Am J Prev Med 29, 120-125.

46. Wethington H, Pan L \& Sherry B (2013) The association of screen time, television in the bedroom, and obesity among school-aged youth: 2007 National Survey of Children's Health. J Sch Health 83, 573-581.

47. Drygas W, Kwaśniewska M, Kaleta D et al. (2008) Increasing recreational and leisure time physical activity in Poland how to overcome barriers of inactivity. J Public Health 16, 31-36.

48. Chabros E, Charzewska J, Rogalska-Niedźwiedź M et al. (2008) Low physical activity of adolescents promotes development of obesity. Probl Hig Epidemiol 89, 58-61 (in Polish).

49. Jodkowska M, Tabak I, Oblacińska A et al. (2013) Sedentary behaviours 13-year-olds and its association with selected health behaviours, parenting practices and body mass. Med Wieku Rozwoj 17, 165-173 (in Polish).

50. Albuquerque D, Nobrega C \& Manco L (2012) Assessment of obesity and abdominal obesity among Portuguese children. Acta Med Port 25, 169-173.

51. Hare-Bruun H, Nielsen BM, Kristensen PL et al. (2011) Television viewing, food preferences, and food habits among children: a prospective epidemiological study. $B M C$ Public Health 11, 311

52. Lissner L, Mehling K, Sjöberg A et al. (2013) Secular trend in weight, height and BMI in young Swedes: the 'Grow up Gothenburg' studies. Acta Paediatr 102, 314-317.

53. Ariza AJ, Chen EH, Binns $\mathrm{HJ}$ et al. (2004) Risk factors for overweight in five-to six-year-old Hispanic-American children: a pilot study. J Urban Health 81, 150-161.

54. Beyerlein A, Toschke AM, Schaffrath Rosario A et al. (2011) Risk factors for obesity: further evidence for stronger effects on overweight children and adolescents compared to normal-weight subjects. PLoS One 6, e15739.

55. Perek M, Krzeczowska B \& Twarduś K (2003) Nutritional behaviours of youth during adolescence. Ann Univ Mariae Curie Sklodowska Sect D Med 58, Suppl. 13, S474-S478 (in Polish).

56. Mota J, Fidalgo F, Silva R et al. (2008) Relationship between physical activity, obesity and meal frequency in adolescents. Ann Hum Biol 35, 1-10.

57. Włodarczyk-Bisaga K, Dolan B, McCluskey S et al. (1995) Disordered eating behaviour and attitudes towards weight and shape in Polish women. Eur Eat Disord Rev 3, 205-216. 
58. Brown PJ \& Konner M (1987) An anthropological perspective on obesity. Ann N Y Acad Sci 499, 29-46.

59. Rathner G (2001) Post-communism and the marketing of the thin ideal. In Eating Disorders and Cultures in Transition, pp. 93-104 [M Nasser, MA Katzman and Gordon RA, editors]. East Sussex: Brunner-Routledge.

60. Kowal M, Cichocka BA, Woronkowicz A et al. (2011) Międzypokoleniowe zmiany $w$ budowie ciała $i$ akceleracja pokwitania $u$ dzieci $i$ młodzieży $w$ wieku 7-15 lat $z$ populacji wielkomiejskiej w świetle uwarunkowań psychosocjalnych. Monografie nr 5. Kraków: AWF.

61. Pilecki MW, Kowal M, Woronkowicz A et al. (2013) Psychometric properties of Polish version of the Children's Eating Attitudes Test. Arch Psychiatr Psychother 1, 35-43.

62. Sobaś K, Wądołowska L, Słowińska MA et al. (2012) Effect of slimming diets used in the past on body composition, calcium consumption and physical activity of girls. Probl Hig Epidemiol 93, 804-811 (in Polish).

63. Krawczyński M, Czarnecka A, Wysocka-Gryczka K et al. (2001) Obesity in children and teenagers in the city of Poznań (Poland). Etiopathogenetic, epidemiology and social aspects. Now Lek 10-11, 1110-1119 (in Polish).

64. Tutkuviene J (2005) Sex and gender differences in secular trend of body size and frame indices of Lithuanians. Anthropol Anz 63, 29-44.

65. Moreno LA, Moliner-Urdiales D, Ruiz JR et al. (2012) Five years trends on total and abdominal adiposity in Spanish adolescents. Nutr Hosp 27, 731-738.

66. Neumark-Sztainer D, Wall M, Eisenberg ME et al. (2006) Overweight status and weight control behaviours in adolescents: Longitudinal and secular trends from 1999 to 2004. Prev Med 43, 52-59.

67. Kowal M, Kryst L, Woronkowicz A et al. (2013) Long-term changes in BMI and adiposity rebound among girls from
Kraków (Poland) over the last 30 years (from 1983 to 2010). Am J Hum Biol 25, 300-306.

68. GuO X \& Ji C (2011) Earlier menarche can be an indicator of more body fat: study of sexual development and waist circumference in Chinese girls. Biomed Environ Sci 24, 451-458.

69. Adair LS (2008) Child and adolescent obesity: epidemiology and developmental perspectives. Physiol Behav 94, 8-16.

70. De Leonibus C, Marcovecchio ML \& Chiarelli F (2012) Update on statural growth and pubertal development in obese children. Pediatr Rep $\mathbf{4}$, e35.

71. Taylor RW, Falorni A, Jones IE et al. (2003) Identifying adolescents with high percentage body fat: a comparison of BMI cutoffs using age and stage of pubertal development compared with BMI cutoffs using age alone. Eur J Clin Nutr 57, 764-769.

72. Kryst L, Kowal M, Woronkowicz A et al. (2012) Secular changes in height, body weight, body mass index and pubertal development in male children and adolescents in Krakow, Poland. J Biosoc Sci 44, 495-507.

73. Maciejczyk M, Cempla J \& Gradek J (2015) The somatic development of obese and non-obese boys between 9 and 12 years of age. J Med Sci $\mathbf{1}$, issue 84, 597-602.

74. Walvoord EC (2010) The timing of puberty: is it changing? Does it matter? J Adolesc Health 47, 433-439.

75. Moss A, Klenk J, Simon K et al. (2012) Declining prevalence rates for overweight and obesity in German children starting school. Eur J Pediatr 171, 289-299.

76. Jakimaviciene EM \& Tutkuviene J (2007) Trends in body mass index, prevalence of overweight and obesity in preschool Lithuanian children, 1986-2006. Coll Antropol 1, 79-88.

77. Ebbeling CB, Pawlak DB \& Ludwig DS (2002) Childhood obesity: public-health crisis, common sense cure. Lancet 360, 473-482. 